\title{
Telling the Story of Globalization, Neoliberalism and the Call Centre Industry in New Brunswick
}

\author{
Joan McFarland St. Thomas University
}

\begin{abstract}
Résumé
Au Nouveau-Brunswick, au début des années quatre-vingt-dix, le gouvernement libéral de Frank McKenna a opté pour la mondialisation et le néolibéralisme, en créant un secteur de centres d'appels. Ou, du moins, cela semblait constituer l'adoption d'une stratégie de mondialisation néolibérale. Sauf qu'un examen plus approfondi des propos tenus alors met en lumière une position très particulière envers la mondialisation néolibérale - celle d'une province démunie ayant recours en dernier ressort à cette stratégie de développement économique. Vu l'intérêt récemment porté par les chercheurs à la diversité des significations et des implications de la mondialisation et du néolibéralisme, le cas du Nouveau-Brunswick constitue un point de départ particulièrement intéressant à une réflexion sur ces débats.
\end{abstract}

\begin{abstract}
In New Brunswick, in the early nineties, the Liberal government of Frank McKenna embraced both globalization and neoliberalism in the creation of a call centre industry. It seems a classic case of the adoption of a globalization and neoliberal strategy. However, further examination of the discourse of the period shows a very particular positioning vis-à-vis globalization and neoliberalism. It is one adopted by a 'have-not' province as a kind of desperate economic development strategy. Given recent attention in the literature to the various meanings and implications of globalization and neoliberalism, the New Brunswick case gives a particular vantage point from which to reflect on these debates.
\end{abstract}




\section{Introduction}

In New Brunswick, in the early nineties, the Liberal government of Frank McKenna embraced both globalization and neoliberalism. The cover of McKenna's 1993 policy strategy document, Toward Self-sufficiency: Strategy for Economic Development, shows a globe with lines emanating from New Brunswick to all parts of the world (New Brunswick, 1993). At the same time, full page ads were placed in the Globe and Mail with a huge picture of Frank McKenna declaring "New Brunswick is Open for Business!" Back in the province, there were cuts to social programs, lowered corporate tax rates and regulations and active promotion of New Brunswick as a low cost investment destination.

It seems a classic case of the adoption of a globalization and neoliberal strategy. However, further examination of the discourse of the period shows a very particular positioning visà-vis globalization and neoliberalism. It is one adopted by a 'have-not' province as a kind of desperate economic development strategy. The meanings and implications of the terms globalization and neoliberalism have been debated in the literature. The terms appear both separately and in combination.

James Petras and Henry Veltmeyer, in their book, Globalization Unmasked, suggest that the term globalization is used both as a "description and a prescription" (2001: 11). At a basic level, globalization can be described as the "the widening and deepening of the international flows of trade, capital, technology and information within a single integrated global market" (Petras and Veltmeyer, 2001: 11). However, this description belies two diametrically opposed meanings and implications. First, there is the technologically driven, structural view of globalization:

One of the central tenants of globalization theorists is the idea that globalization is inevitable, that technological, economic and political developments have converged so as to exclude any forms of economic growth other than that based on transnational flows of capital and commodity trade (Petras and Veltmeyer, 2001: 11).

Petras and Veltmeyer contrast this with their view of globalization in which "the network of institutions that define the structure of new global economic systems is viewed not in structural terms, but as intentional and contingent, subject to the control of individuals who represent and seek to advance the interests of a new international capital class" (2001: 12). In fact, they suggest, the term globalization is "imprecise, euphemistic and obfuscating" and should be replaced by the term, "imperialism"- an imperialism where "multinational corporations and banks and the imperial states (are) the driving force of the international flows of capital and commodity trade" $(2001: 75,30)$.

Under this definition of globalization or imperialism, global corporations are the leading 
actors but the state also plays a major role. It acts as facilitator and catalyst by changing its policy regime to meet the needs of global capital. As Leo Panitch (2003: 17) argues: "Far from being the victims of globalization, states are often better seen as the authors of it."

As a prescription, globalization is an ideological doctrine, adopted even by the United Nations Development Program (UNDP), involving "the belief that free flows of trade, capital and information will produce the best outcome for growth and human welfare" (Petras and Veltmeyer, 2001:11).

Neoliberalism, which notably is a term used only by its critics, can also be seen as both a description and a prescription. As a description, it has been defined as "the ideological and practical rejection of the Keynesian welfare state and its replacement with free-market doctrines and practices" (Naiman, 2004: 215). These policies and practices have been adopted not only in the North but also have been implemented in the South, imposed by the IMF and World Bank, as structural adjustment programs (SAPs). There are other related definitions of neoliberalism such as: "the systematic use of state power to impose (financial) market imperatives" and "a particular organization of capitalism, which has evolved to protect capitalism and reduce the power of labour" (Saad-Filho and Johnston, 2005: 3). Under such definitions, neoliberalism has been called "the corporate agenda" since its underlying goal "is nothing less than a massive transfer of wealth and power to the corporate sector" (Naiman, 2004: 215).

Joseph Stiglitz, in a recent interview, describes the ideology surrounding neoliberal policies as "that grab-bag of ideas based on the fundamentalist notion that markets are self-correcting, allocate resources efficiently and serve the public interest well" (Stiglitz 2008: online). None of this, he adds, has any basis in either economic theory or historical experience. Rather, the results of neoliberalism have been disastrous for both developed and developing worlds.

In their introduction to Neoliberalism: A Critical Reader, Alfredo Saad-Filho and Deborah Johnston suggest that neoliberalism is indistinguishable from globalization and imperialism. They see globalization as merely "the international face of neoliberalism" where neoliberalism is "part of a hegemonic project concentrating power and wealth in elite groups around the world, benefitting especially the financial interests within each country, and US capital internationally" (2005: 3). As a result of this convergence of neoliberalism and globalization, Saad-Filho and Johnston adopt the term 'neoliberal globalization'.

Hugo Radice, in a passage from an article in Neoliberalism: A Critical Reader, describes neoliberal globalization as follows: 


\section{Telling the Story of Globalization, Neoliberalism and the Call Centre Industry in New Brunswick}

Within the overarching ideology of neoliberalism, the norms of government for capitalist nation-states have been reorganized around the ideology of international competition. The message for workers is that employment and security can only be guaranteed by winning world markets on the basis of low costs, and that since only the private sector is efficient in doing this, capitalists must be enticed to invest by the prospects of high profits and low taxes. This is the domestic politics of 'there is no alternative': in every country, the same arguments are used to cut welfare, to privatize and to deregulate labour markets. This is the new form taken for the central purpose of the capitalist state- to manage labour on behalf of capital (2005: 96-97).

Some questions arise from these views of globalization and neoliberalism which we can address from the perspective of the New Brunswick call centre case study. Which of these definitions describe what is going on in New Brunswick? Are globalization and neoliberal policies being used in New Brunswick mainly as ideological doctrines? Should globalization and neoliberalism in New Brunswick be seen as inevitable or as intentional? What is the role of global corporations? What is the role of the state? In most instances, are globalization and neoliberalism inextricably linked?

\section{McKenna and the 1993 Toward Self-Sufficiency Document}

A close reading of McKenna's Toward Self-Sufficiency document reveals that the arrows from New Brunswick in the image described above do not represent bold new initiatives for New Brunswick in trade and investment abroad but rather the opposite - the attraction of more global investment to New Brunswick. The role of the global economy is seen not as providing opportunities for New Brunswick to be a player on the global stage but in demanding what New Brunswick must offer to global capital. It is the 'global competition' resulting from globalization which dictates and this 'global competition' requires significant changes in the New Brunswick economy:

Technology and innovation and their application through investment and trade have brought global competition to our door (New Brunswick, 1993: 11).

The document declares that New Brunswick needs "competitive costs" to establish a "competitive advantage" with the goal of making New Brunswick "a location of choice to invest, work and live (italics mine)" (New Brunswick, 1993: 15, 45, 10). The term 'globalization' is never mentioned in the document and neither is 'neoliberalism'.'

Furthermore, only some of the neoliberal policies that were later introduced in the province are mentioned or even hinted at. One exception is the achievement of "sound

1 In the late nineties, a former McKenna aide was in my Introductory Economics course. Just when I was feeling most self-conscious about my critical approach to the capitalist economic system and neoliberal policies, he raised his hand in class and asked, "What is neoliberalism?" 
finances"- meaning the elimination of deficits and the debt in New Brunswick (New Brunswick, 1993: 16). The hints include a disparagement of the overuse of unemployment insurance in the province (New Brunswick, 1993: 15). Another is praise for the "selfreliance" achieved by women formerly on welfare on the government's New Brunswick Works program, the province's version of workfare (New Brunswick, 1993: 32). In another part of the document, it is claimed that there is the need for "better labour management" without spelling out what that might mean (New Brunswick, 1993: 46). The advantage of "partnerships", including public-private partnerships, is mentioned frequently, but somewhat vaguely (New Brunswick, 1993: 18, 20, 25-26). Improving infrastructure in the province - with federal assistance - is also part of the strategy (New Brunswick, 1993: 13, 39). Although there are many allusions to achieving higher productivity through technology and innovation, the real thrust of the argument in the document is towards the lowering of the cost of doing business in the province.

In the early days, when talking about bringing investment to New Brunswick, McKenna always mentioned innovation and new technology - the 'information highway' was a favourite concept (Meagher, 1995). However, what he brought, in the end, was mostly call centres. How, in the nineties, he used neoliberal policies to turn New Brunswick into what has been called 'the call centre capital of North America' is discussed below.

\section{Neoliberalism and the Creation of a 'Global' Industry'}

Labour intensive, fast growing and footloose, the call centre industry was bound to catch the attention of governments in high unemployment areas like New Brunswick. The province has a long history of double-digit unemployment and low labour force participation. Outmigration has been the traditional adjustment mechanism as surplus labour has been siphoned off to other parts of Canada during boom periods, but this process normally slows or even reverses during economic downturns (Veltmeyer, 1979: 26ff). Given the lacklustre performance of the Canadian economy in the 1990s, and the erosion of jobs in New Brunswick's traditional base of forestry, mining and fishing, the province faced a decade with 40,000 officially unemployed, 20,000 part-time workers seeking full-time work, about 15,000 self-employed on the margins of the economy, and an estimated 30,000 discouraged workers outside the official labour market (Statistics Canada, 1999). Overall, the estimated labour surplus in the province totaled almost 100,000; about 25\% of the labour force.

Motivated by the political imperative of job creation, the Liberal government of Frank McKenna launched his campaign to promote the development of the knowledge-based service sector, of which call centers represent a significant part (New Brunswick/NBTel, 1999: 6). The new strategy signaled a major departure from old-style development strategies, which had focused on expanding male job opportunities in the resource extraction and manufacturing sectors. The new approach meant that, for the first time,

2 This section of the paper is largely based on the discussion in Good and McFarland (2004). 


\section{Telling the Story of Globalization, Neoliberalism and the Call Centre Industry in New Brunswick}

the government's job creation activities were aimed at non-core segments of the labour market.

The early years were characterized by a number of false starts and unmet expectations, as the government groped toward a workable strategy. Initially the government hoped that call centres would employ many of the 3000, mostly female, participants in the muchheralded New Brunswick Works training programme designed to move welfare recipients into paid labour. But these expectations went largely unrealized as employers took advantage of other options in the labour market; for example, the first call centre to locate in the province, Camco (a subsidiary of General Electric), hired only university graduates who were also bilingual (N.B. web site 1996). Provincial planners anticipated that New Brunswick would have a competitive advantage in call centre recruitment because of its large supply of bilingual workers. But any advantage turned out to be short-lived except for outbound call centres as new switching technology enabled customers to access unilingual agents ("for service in English, press 1"). Another possibility that failed to materialize was the hope that call centres might pick up the slack as older workers were displaced from manufacturing and the resource industries.

From the government's perspective, the major challenge was to interest large corporations that were proceeding with call centre development to consider locating these activities in New Brunswick. The Premier, assuming the role of chief salesman, even set up his own toll-free line: 1-800-McKenna. The results were slow at first, but by the latter part of the decade he and his colleagues had succeeded in recruiting a number of call centres operated by Canadian companies and Canadian-based subsidiaries of American multinationals, including Camco, UPS, Air Canada, Royal Bank, and Canada Post. ${ }^{3}$ In the late 1990's, the pace of growth accelerated dramatically and call centre employment in New Brunswick tripled. By 2001, it was estimated that there were 15,000 call centre jobs in New Brunswick providing work for one employee in every fifteen in the province's private sector (New Brunswick Economy, 2002). The pattern of growth changed, with more arrivals coming directly from the U.S., including inbound call centres operated by Unilever, Speigel and Xerox (which simultaneously closed its Rochester location), and outbound centres operated by large multi-site companies such as $\mathrm{RMH}^{4}$ and $\mathrm{ICT}^{5}$.

From its earliest conception, the New Brunswick call centre project was a state-sponsored initiative, in collaboration with the local private-sector telephone company, NBTel. The extensive, almost organic, partnership between a large corporation and the government was not new to New Brunswick; rather, it was the continuation of a particular form of corporatism that has existed for decades in the province's resource-extraction and manufacturing

3 Up until the last five years or so, lists of call centres located in the province were provided by the New Brunswick Department of Development and Tourism.

4 RMH Teleservices Inc.

5 ICT Group. 
sectors (dominated by Irving, McCain, and Noranda). The NBTel/Government team provided single point of contact for prospective call centres (referred to as 'customers' in their promotional materials): NBTel promised them competitively priced, up-to-date technology, while the government promised to deliver a low cost workready workforce. In the words of one of their joint publications (New Brunswick/NBTel, 1999:7):

The partnership works! Both the Province of New Brunswick and NBTel believe in a lifetime commitment to their customers - customers truly are their business... They work hard every step of the way to ensure the success of their customers.

NBTel (now part of Aliant) was the first telephone company in Canada to construct a full fibre-optic network, and it prided itself in its innovative capacity. The company employed over 250 staff in call centre support, offering new centres assistance with:

design and set-up of the centre, telephone design, partnership strategies, full installation and testing of telecommunications infrastructure, real estate acquisition ... as well as recruiting and training. This turnkey solution is provided at no charge! (New Brunswick/NB Tel, 1999: 7)

In addition, NBTel offered 24-hour support services, and the use of telecommunications equipment with no capital outlay:

NBTel's Business Communications Service (BCS) is a unique business approach to providing telecommunications service, where call centres are charged on a peragent, per-month basis. NBTel will purchase most telecommunications hardware and software.... This protects call centres from financial risk, since they are not required to outlay any capital to establish their telecommunications platform. NBTel maintains and upgrades the platform, which reduces the call center's business risk (New Brunswick/NB Tel, 1999: 7).

By increasing the volume of calls on its system, NBTel could increase profitability given the declining marginal costs which are characteristic of the industry. While the telephone company received no direct subsidy, it had received significant indirect assistance since 1994 when the government removed the $11 \%$ provincial sales tax on telephone bills for 1-800 numbers.

The government's direct subsidies focused primarily on labour costs, the crucial budget item for most call centres. From the outset, New Brunswick offered cash incentives to businesses to locate call centres in the province. Payments were normally in the form of three-year forgivable loans, which need not be repaid if specified employment targets 


\section{Telling the Story of Globalization, Neoliberalism and the Call Centre Industry in New Brunswick}

are met. Ostensibly, the government money was for training, recruiting, and set-up costs, and was not an operating subsidy. However, the practice was to provide assistance based on ten percent of the estimated overall wage bill for a call centre's first three years of operation (Hrabluk and Tutton, 1999). The ten-percent figure is approximately equal to the amount of income and other taxes which the New Brunswick government would have expected to collect from employees of a new call centre during this three year period. In the 1991-2001 period, call centres received close to $\$ 50$ million in forgivable loans and grants, an average of about $\$ 6,000$ per full-time job equivalent, with some early centres (including Camco and UPS) receiving over \$10,000 a job (Buchanan and Koch-Schulte, 2000: 93). In the 1990s only a handful of centres in the province (including the Royal Bank and Canada Post) did not receive forgivable loans.

New Brunswick's cash-for-jobs payments were subject to bilateral negotiation with each firm. In the words of a government representative heavily involved in the process, borrowing from the lexicon of the private sector: We bid the job. ${ }^{6}$ This allowed each bid to be adjusted in the light of competing offers. Not surprisingly, other provincial governments attacked these deals as 'job poaching' and 'race to the bottom' competition, particularly the $\$ 11$ million paid to UPS, the world's largest private sector courier for 1,030 jobs relocated from British Columbia and Ontario (Buchanan and Koch-Schulte, 2000: 93). However, neither the size of the subsidies nor the use of beggar-thy-neighbour policies to increase labour demand were contentious issues in New Brunswick.

Call centres on the low road, of course, consider not only initial wage costs in determining site location, but also the prospect of on-going, low and stable wage rates. This explains in large part their migration towards pockets of unemployment, like New Brunswick. Chronic high unemployment tends to lower the whole wage structure, since workers lack good alternative employment opportunities. For women, whose average wages are considerably less than men's, and young people, whose wage rates have actually been falling in the 1990s, the depressed region effect tends to reduce their low wages still further. Moreover, these high unemployment areas have low labour force participation rates (i.e. the percentage of a particular population employed either full-time or part-time or actively seeking work). A low participation rate may be attractive to employers because it implies the existence of an untapped supply of labour that can be mobilized to offset any upward pressure on wages. In 1991, the participation rate for women over 25 years of age in New Brunswick was seven percentage points below the Canadian average $(49.7 \%$ vs. $56.7 \%$ ), and for youth aged 15 to 24 it was nearly ten percentage points (58.5\% vs. $68.0 \%$ ) below the national average (Statistics Canada, 2000). For call centre operators, therefore, the economic conditions in the province in the 1990s offered good prospects for finding capable workers at low and stable wage rates.

6 Interview with Brian Freeman, New Brunswick Dept. of Economic Development and Tourism, 16 May 1997. 
Quite simply, the New Brunswick government's call centre initiative was developed as a set of neoliberal policies to accentuate the advantages to employers of operating in this labour market by: (i) lowering non-wage payroll expenses; (ii) increasing the available labour supply; and (iii) maintaining a non-union work environment in the province.

Non-wage payroll costs are always a concern for employers in labour intensive industries, and many of these costs can be influenced directly by government policy. In the early 1990s the provincial government implemented changes to workers' compensation, which restricted claims and reduced benefits (New Brunswick Workers' Compensation Board, 1992). As a result, premiums paid by employers in New Brunswick were set at rates which were near the lowest in Canada, and coverage for injured workers was substantially reduced. Especially significant for the call centre industry, claims based on workplace stress were disallowed except as the result of a traumatic event and claims based on soft tissue injuries were severely curtailed by bureaucratic means. To support the industry further, a special reduced-premium classification was created for call centres.

For its part, the federal government also reduced employer payroll costs when it radically transformed the unemployment insurance programme in the mid-1990s, restricting eligibility and curtailing benefits. Once again, the burden fell on workers as programme changes reduced the level of weekly benefits and dramatically cut the maximum number of weeks of benefit entitlement. Eligibility was curtailed by increasing the hours of work time required to qualify for benefits, and benefits were denied to anyone leaving a job without just cause. As a result, a programme which had provided benefits for $83 \%$ of unemployed Canadians in the late 1980s benefited only 32\% by 1997 (Little, 1998: 2). The new rules were particularly onerous for those entering the workforce for the first time, those re-entering the workforce after a significant absence, and those working part-time hours; precisely the people most likely to be employed in call centres.

The second part of the government's programme - increasing the labour supply particularly of female and young workers - was based on a strategy of making the alternatives to paid work increasingly unattractive, rather than making paid work more attractive through improved wages and labour standards. In fact, for most of the 1990s the New Brunswick minimum wage remained at $\$ 5.25$ to $\$ 5.50$ an hour, one of the lowest in Canada, and labour standards were actually eroded. Cutbacks to social programmes and restrictive fiscal policies at both the federal and provincial levels produced stagnating or falling real incomes, especially for families in the middle and lower end of the income distribution scale (Jackson et.al., 2000: 115 ff). This, in turn, increased the pressure on families to try to maintain their incomes by providing additional wage earners. The effect was particularly strong in New Brunswick where, between 1991 and 2000, the participation rate for women over 25 rose by five percentage points (from $49.7 \%$ to $54.6 \%$ ) compared with 


\section{Telling the Story of Globalization, Neoliberalism and the Call Centre Industry in New Brunswick}

a two percentage point increase (from $56.7 \%$ to $58.8 \%$ ) for Canada as a whole (Statistics Canada, 2000).

For students, too, the cost of non-participation in the labour force was also rising. Cuts in government operating grants for post-secondary education, higher tuition fees, and the conversion of student aid almost exclusively into student loans generated a financial crunch for a large number of students. Between the late 1980s and the mid-1990s the average loan for a graduating university student in New Brunswick doubled to about $\$ 15,000$, and it has continued to rise since then. To avoid this heavy debt-load, more and more students sought part-time work; in fact, by the mid-1990s more than half the university students in the province were working both during the school year and in the summer (Maritimes Higher Education Committee, 1998: 41). Call centres clearly stood to benefit: Cendant, for example, made a deal with a local university, in which the company designated certain part-time positions for students and the university provided the workers to fill them. ${ }^{?}$

The government's neoliberal call centre strategy also included an anti-union industrial relations policy, intended to provide employers with the advantages of a weak and divided workforce. The tone was set in 1991 when the McKenna administration provoked a bitter confrontation with its own public sector workers by breaking into signed collective agreements to impose a wage freeze (Lee, 2001). Later in the decade, it sat idly by as three large private sector strikes and lockouts dragged on, not just for months but for years. This anti-union environment was used by the government as a selling point in its call centre initiative. Their 1996 web site was surprisingly candid, pointing out that:

1. the telecommunications industry in New Brunswick has the lowest rate of unionization in Canada

2. some call centres which were unionized elsewhere have consolidated as non-union operations in New Brunswick

3. NBTel is the only telephone company in Canada with non-unionized clerical staff

Even now in New Brunswick, Aliant (previously NBTel) and Air Canada are the only unionized private-sector call centres and Aliant was already organized before it opened its call centre and Air Canada was organized before it moved to New Brunswick. There have been several unionization efforts, including a bitter and unsuccessful fight in 1997 at the UPS call centre in Fredericton. In 1999, workers did successfully unionize the Saint John site of ICT Group, a large U.S.-based call centre business with over 30 locations; however, shortly after, the company closed its Saint John operation. The government took no action whatever to protect the workers rights or their jobs, despite the public funds received by the company (Malik and Tutton, 1999): "You unionize, your job is gone", said Cindy 
Caissie, a 24 year-old telemarketer who had been at the centre for two years. "That's the message here" (Malik and Tutton, 1999).

\section{Changes and New Contradictions in the Call Centre Industry}

It is argued above that the call centre industry in New Brunswick was 'a created industry' which, in the 1990s, used neoliberal policies to bring in global capital. In the years since, there has been continuity in that the same basic strategy is being followed. However, the situation has changed in certain respects and new contradictions have emerged. These changes and resulting contradictions involve the growth of the industry; working conditions; the closure of centres; the opening up of rural centres; the entrance of Business Process Outsourcers; globalization, neoliberalism and a new, enhanced self-sufficiency agenda for New Brunswick under the current Liberal premier, Shawn Graham; and a Statistics Canada prediction for the demise of the industry in its present form.

\section{Growth of the industry}

The call centre industry in New Brunswick has grown from one centre in 1991 to approximately 110 centres with 21,000 workers in 2007 (New Brunswick, Dept. of Finance, 2007: 21). However, job growth in the industry appears to have peaked in the 2000-03 period at 21,400 workers. Some observers attribute the stagnation in job growth to the industry having reached "a state of high-tech maturity" (Shipley, 2007). However, a labour shortage in the form of a lack of new willing workers for the industry is more likely the cause. At the same time, global competition for the attraction of new call centres has increased. This includes competition from offshore locations such as India. There was concern in the summer of 2006 that Minacs, with a centre in Moncton, would move it to India when the company was bought by an Indian company (Times and Transcript, 2006).

\section{Working Conditions in the Industry}

In 1995, McKenna described the call centre jobs he was bringing to New Brunswick as "high quality, highly skilled, high paying and pollution free" (Daily Gleaner, 1995: A1). Each of those claims has proven questionable. The jobs might be described, instead, as highly monitored, stressful, insecure, low paying and lacking union protection.

In a survey of call centre workers in the Fredericton area taken in $2007^{8}$, some changes in the working conditions from the early days were evident (McFarland, 2007). First, the gender composition of workers has altered. Females are still in the majority but to a lesser extent. Males, particularly young males who are high school or university graduates as well as current students working part-time, are playing a much larger role. Second, there is no longer the same distinction in working conditions between outbound centres where sales calls to prospective customers are made and inbound centres where calls from customers

8 This survey was undertaken by the author and involved a questionnaire and taped interviews with twenty call centre workers in the Fredericton area. 


\section{Telling the Story of Globalization, Neoliberalism and the Call Centre Industry in New Brunswick}

about billing, service etc. are received. The telemarketing at outbound centres was said to be stressful while work at inbound centres was seen to be less so. Now, however, there is pressure on inbound centre workers to make sales when customers call in with inquiries and there are pay bonuses for doing so. This greatly increases the stress in these jobs. Third, there have been changes in terms of discipline which, it could be surmised, have come about as a result of the labour shortage. In the early days, particularly at outbound centres, the discipline could be Dickensonian. For example, a worker was refused time off to visit her baby who was in the hospital (McFarland, 1996: 14). Now, presumably because of the labour shortage, discipline in the outbound centres can be quite lax and it is only the number of sales that count. A worker said that when he decided not to return to work after a break, there was no reprimand the next day. Another told of playing video games while making calls. Others described the smell of marijuana in the air at some centres. At the inbound centres, when workers do not meet performance standards, they are not fired but rather, in the words of one worker, "coached to death". Trying to answer all of the customers' questions and consequently taking too long on calls, he was taken aside almost every day for coaching until he could stand it no longer and quit on his own accord. ${ }^{9}$

Another aspect that is evident from the survey is a low level of support for unionization. The majority of the workers interviewed said that they would not be interested in trying to establish a union at their workplace. The main reason they gave was that a union "would not work" in the call centre industry. Workers seemed to be convinced that, if they organized, the call centre would leave the province and they would be out of a job. This message had been delivered to them by the managers at the centres, all local people, and the workers believed it. This ambivalence to unions on the part of workers was very evident when, in the summer of 2007, the Public Service Alliance of Canada (PSAC) attempted to organize the Accenture centre in Fredericton. The union was simply unable to get sufficient support. To add to the defeat, two of the workers involved in the organizing drive lost their jobs at the centre soon after the campaign was abandoned. ${ }^{10}$

\section{Call Centre Closures}

There have been a number of call centre closures in the province. Most of these have happened suddenly leaving both the workers and the province in a difficult situation. The table below shows some of the closures of call centres in New Brunswick since 2000 and the amounts of forgivable loans that the companies had received.

9 This information is from the author's 2007 survey of Fredericton area call centre workers.

10 Information is from the author's 2007 survey of Fredericton area call centre workers. 
Closures of Call Centres and Forgivable Loans, 2000-2007 ${ }^{11}$

\begin{tabular}{|l|l|}
\hline Company (Date of Closure) & Forgivable Loan \\
\hline CanJet (2001) & $\$ 831,000$ \\
\hline Fulford Enterprises (2001) & $\$ 150,000$ \\
\hline Star Choice (2003) & almost \$1 million \\
\hline CAI (2004) & $\$ 425,000$ \\
\hline RMH (2004) & $\$ 2$ million \\
\hline Archway Marketing Services (2005) & $\$ 1.5$ million \\
\hline Salesbridge (2006) & $\$ 1.98$ million $+\$ 2.25$ million \\
\hline ICT Group Inc. (2006) & $\$ 760,000$ \\
\hline Connect North America (2007) & $\$ 300,000$ \\
\hline AOL (2007) & $\$ 1.2$ million \\
\hline
\end{tabular}

An early dramatic pull-out from New Brunswick was Star Choice in 2003. Located in Lincoln which is just outside of Fredericton, the centre answered service calls for Star Choice satellite dishes. The company had received $\$ 413,400$ in forgivable loans in 1998 and another $\$ 444,600$ in 2000 (Daily Gleaner, March 2003). Its closure came as a surprise with the company giving the reason of an internal restructuring of the company. The two hundred and forty-three workers who lost their jobs were left in a very difficult situation. A number of them were unable to get unemployment insurance due to a mix-up over when they should leave after the company's announcement (McLaughlin, 2003). A year later, another call centre, RMH, an American based transnational telemarketer, closed its doors without warning and six hundred workers lost their jobs. No reason was given for the closure but the rumour was that their big AT\&T contract had been given to India. Workers claimed to have been "robbed of four weeks pay" when their status was changed

11 Sources for Table: "Minister Promises Help for Bathurst after CanJet Centre Hangs Up" (New Brunswick Telegraph Journal, April 4, 2001); "Call Centre in Job-Starved Dalhousie to Close: Lack of Employees. Fulford Enterprises was Sued by Five Former Employees for Wrongful Dismissal, Sullying its Reputation in the Town" (New Brunswick Telegraph Journal, September 11, 2001: Money Section); "Star Choice Decision Sends Direct Message" (Daily Gleaner, March 29, 2003: Opinion Section); "Development Agency Determined to Replace Campbellton Call Centre: Strong Canadian Dollar Blamed for CAI Facility's Sudden Closure" (New Brunswick Telegraph Journal, November 18, 2004: Money Section); "Call Centre Closing its Doors: More than 600 People will be out of Work with the Closure of RMH Teleservices in Oromocto" (New Brunswick Telegraph Journal, July 30, 2004: News Section); “75 Workers Lose Jobs as Call Centre Shuts Doors" (New Brunswick Telegraph Journal, August 12, 2005: News Section); "Call Centres Close Suddenly; Hundreds of Workers out of Work as Company Padlocks Fredericton, Bathurst Centres" (Times and Transcript, August 30, 2007: Business Section); "AOL cuts 140 Metro Jobs; Company cuts Support Staff for U.S. Internet service" (Times and Transcript, October 17, 2007: News Section); "292 will Lose Jobs; Closing Stream International Call Centre Shutting Down” (NB Telegraph Journal, February 1, 2008: News Section). 
from "terminated" to "laid off" at the last minute (NB Telegraph Journal, 2004: online). In 2006, Salesbridge, which had been touted as a "high end" call centre because it sold Ikon services to business customers in the United States, laid off 270 workers in its Saint John and Fredericton call centres. The company, which had been formed as a partnership between Marketbridge, an American global corporation, and Innovatia, a branch of Aliant (the current NB telephone company), had opened in Fredericton the previous year to great fanfare and instalments of \$1.98 million and \$2.25 million in forgivable loans (Duplain, 2005). The partnership was dissolved in 2006 and, by June 2007, all of the remaining thirty-two workers were laid off (Daily Gleaner, 2007). Later that summer, Connect North America, an American company that had been operating in New Brunswick in different locations since 1992, closed its doors, also without warning, on its three hundred workers in Fredericton and Bathurst. As the local newspaper described it:

The employees of Connect North America came to work for their 10am shift only to find the doors locked and a small sign saying that the facility was closed (Llewellyn, August 2007).

Workers were concerned that they wouldn't get their last paycheques or performance bonuses. They did get their last paycheques the following Friday but they had to line up in the parking lot for them (Llewellyn, September 2007). Since they didn't get any severance pay, some filed written complaints with the Labour Department. However, they were told that it could take anywhere from four months to four years to resolve their complaints.

\section{Rural call centres: VAS, Aliant and VoIP}

A recent development has been the establishment of rural call centres in the province. All of them are operated by one company, Virtual Agent Services (VAS), with technical assistance from Aliant. But while VAS has become the poster child for the government call centre strategy, VAS workers are the lowest paid and endure the worst physical working conditions of any call centre workers in the province.

VAS entered the New Brunswick call centre market in 1999. Illinois based with American clients, VAS operates only in New Brunswick. Originally, the company planned to be a 'virtual' call centre using home-based agents rather than locating workers in centres. That idea has not gone very far but over the period of the last nine years, the company has opened twenty-one centres in rural communities and employs more than 1,400 workers (New Brunswick Communications, 2008). The New Brunswick government has supported the company from the beginning with forgivable loans of $\$ 7,500$ for every job created. In addition, VAS has worked closely with Aliant in adopting VoIP (voice over internet protocol) which allows the company to run its network of call centres as if it were one big centre:

Because it uses Aliant's server in Saint John, all incoming calls dial a Saint John 
number, landing on Aliant's hosted switch. Aliant's technology converts the call into an IP signal and sends it over the company's LAN network to an agent in Neguac, Petiticodiac or Minto...Regardless of where they are, they are fully efficient and the next one will take the call (NB Telegraph Journal, October 2007: online).

At a recent press conference, the government announced its signing for "a third phase of growth" with VAS which has promised to create 500 more jobs (New Brunswick Communications, 2008). The relationship is seen as one of partnership both between the government and VAS and between Aliant and VAS. In the premier's words:

Our government is proud to continue to work in partnership with VAS as it grows and creates even more job opportunities for New Brunswickers. New Brunswick is being recognized by firms nationally and internationally as the place to be for business success, and VAS's continued growth is a testatment to that (New Brunswick Communications, 2008: online).

In contrast to this rosy picture, an interview with a worker at one of these rural centres revealed that the pay was the lowest of any call centre in our survey - barely above the minimum wage - and the physical working conditions were distinctly unhealthy. The company has the practice of leasing space in unused municipal buildings such as community centres or schools. The worker that we interviewed was suffering from severe migraine headaches due to the presence of mould in the basement of the community hall where she worked.

\section{Business Process Outsourcers}

The current trend in the call centre industry is outsourcing. In New Brunswick, this has meant the entrance of Business Process Outsourcers or BPOs. BPOs are even more footloose than the global corporations such as Xerox, Avis and the banks which entered the New Brunswick call centre industry in the 1990s.

BPOs are transnational companies, often huge, whose raison d'etre is to provide a range of business services, including call centres, on a contract basis, to other companies, mostly transnational companies as well. ${ }^{12}$ As with other outsourcers, the location for the actual provision of the services can be spread to different parts of the world, based on cost/profit criteria. MarketBridge, Accenture, Minacs, ClientLogic/Sitel, CentreBeam, Teletech, Atelka are all BPOs which have located call centres in New Brunswick.

Accenture describes itself as operating "multiple call centres 24/7 across 5 time zones

12 "Business Process Outsourcing (BPO) refers to the rearrangement of entire business functions to other service providers. The service provider may be either self-owned or a third party... Generally $\mathrm{BPO}$ activities include internal business processes- sometimes referred to as $\mathrm{G} \& \mathrm{~A}$, or general and administrative services, such as human resources (HR), finance and accounting (F \& A), Customer Relationship Management (CRM), and other back office services" (InPro Solutions, 2006: 3). 


\section{Telling the Story of Globalization, Neoliberalism and the Call Centre Industry in New Brunswick}

producing 50 million bills and conducting 30 million metre readings annually" (2008: online). ClientLogic/ Sitel "operates in 52 facilities in 13 countries throughout North American, Europe, Asia and Africa" (2008: online). Minacs claims "a market capitalization of \$120 million and sales over the last year [2006] of \$200 million”, (Times and Transcript, August 2006). CentreBeam is a California Silicon Valley company "specializing in customer outsourcing" (2008: online). Marketbridge, which left the province in 2006, described itself as an "integrated sales and marketing consultant offering managed services to Fortune 500 companies such as Microsoft, IBM, SAP, Merck, Philips, Siemens, Mastercard and BT" (2008: online). Teletech is an Australia based BOP which opened a call centre in St. Basile, New Brunswick in June 2007. They received \$1.6 million in forgivable loans from the government for the creation of 300 jobs (Shipley, 2007). Teletech also had two call centres in Nova Scotia having been offered, in 2003, \$11.8 million in payroll rebates if 1495 jobs were created. In April 2008, Teletech closed its Halifax centre and laid off 485 workers giving the reason as "a decision by a Teletech client" (Erskine, 2008: online). Atelka, a Montreal based BPO, which recently opened a centre in Fredericton - already having one in Saint John - describes itself, on its website, as "providing call centre outsourcing around the world" with 24/7 telephone based and online support (2008: online). It just set up a call centre in Lebanon.

\section{Globalization, Neoliberalism and the New Graham Government}

The new Graham government, elected in 2006, is following McKenna's globalization and neoliberal policies. In terms of globalization, there has been an AIMS (Atlantic Institute of Market Studies) and business initiative in the region called 'Atlantica'. Closely related to the continent-wide Security and Prosperity Partnership (SPP), Atlantica seeks integration of the Atlantic region of Canada with northeastern United States. It envisions a supercorridor from a Halifax super-port through New Brunswick into Maine and beyond with container trade from Europe and Asia, energy integration between the Canadian and US regions and the harmonization of regulations affecting exports, imports and investment between the two countries (Sinclair and Jacobs, 2007: 5-7). Although the New Brunswick government has not officially signed onto Atlantica, there is indication of full commitment to it.

Another aspect of the government's globalization strategy is put forward in the new selfsufficiency document entitled The Self-sufficiency Task Force Report (New Brunswick, 2007). The plans involve a drive to greatly increase energy exports from New Brunswick to the US market. To accomplish this, an energy hub is to be created in Saint John and the surrounding area with the building of a natural gas pipeline, a LNG terminal, a second oil refinery, and the refurbishment of the Point Lepreau nuclear power plant.

In terms of neoliberalism, the evidence seems clear as well. The social cuts, including those 
to unemployment insurance, remain and the minimum wage has only gone up marginally. It is now $\$ 7.75$ which is still the third lowest in the country. The major new initiative involves the reform of corporate taxes, using the Irish model, "with the purpose of better facilitating wealth generation by all New Brunswickers, and making the province more attractive to investment and high-paying jobs" (Ceridian Canada, 2008). Jack Mintz, the former CEO of the C.D. Howe Institute, was invited to Fredericton where he advised the Minister of Finance to cut corporate taxes by up to eight percent "if it wants to attract more international business to set up shop in the province" (CBC, 2007: online). Such proposals are put forward in the government's June 2008 Discussion Paper on New Brunswick's Tax System leading one critic to comment that these are "possibly the most regressive proposals put forward by any government anywhere in Canada" (CUPE, 2008: 1). Further, there is no change since the McKenna era in either the anti-union stance or the active promotion of New Brunswick as a low cost destination for investment. In fact, in a recent local newspaper story based on calculations by KPMG, the most quoted international consulting firm on business competitiveness, New Brunswick cities are touted as "high among top places to do business [italics mine]" (Lewis, 2008: online). In this case, "high" and "top" are in terms of "low cost".

\section{Call Centres and the New Self-sufficiency Agenda}

There is a contradiction between Graham's renewed call for self-sufficiency in the province and the proposed significant job creation role for the call centre industry in that agenda. For the government, self-sufficiency refers to New Brunswick's casting off of its status as a 'have-not' province and thus no longer being dependent on Ottawa (Self-sufficiency Task Force Report, 2007: 5). It has nothing to do with casting off dependence on foreign capital and, instead, there are recommendations for active measures to attract such investment. As a result, the strategy will produce further dependency for the province and not selfsufficiency under any generally accepted definition of that term.

The same person, Frances McGuire, has been a behind-the-scenes architect of both selfsufficiency strategies. McGuire had been a principal advisor to Frank McKenna in the nineties and, in 2007, was the co-chair of the Self-sufficiency Task Force. In a March 2007 opinion piece in the Moncton Times and Transcript, McGuire and his co-chair on the Task Force, explain New Brunswick's challenges and solutions as they see them:

For a variety of reasons - history, geography, a small population and the political and financial pull of central Canada - the Atlantic provinces have always struggled to attract the attention of investors willing to take a risk on this region.... Both of us have sat around boardrooms in these and other major centres [Toronto's Bay Street had been mentioned], selling investors on the idea of New Brunswick and on the potential business opportunities that it offers... To be frank, New Brunswick is a hard sell to people who bring to the table old assumptions and tired stereotypes. It is 


\section{Telling the Story of Globalization, Neoliberalism and the Call Centre Industry in New Brunswick}

time to stop knocking on closed doors; instead we must fashion our own set of keys (Lepage and McGuire, 2007: online).

The role of the call centre industry in the agenda for self-sufficiency is outlined in the Report as follows. The backdrop for the analysis and recommendations involves population decline and a consequent labour shortage in the province, specifically a 25,000 decline in population is forecast for 2026, the year for the attainment of "self-sufficiency". Therefore, the Report suggests, 70,000 new jobs are needed by 2026 and at least half of those will have to come from "big firms that move into New Brunswick" (Self-sufficiency Task Force Report, 2007: 8). Of these 35,000 jobs, 15,000 are slated for call centres. To add to the pressure, the call centre jobs are to be created in the next fifteen years, not the twenty years to 2026 (Self-sufficiency Task Force Report, 2007: 208).

Despite the important job creation role for the call centre industry in the Report's proposals, the industry is scarcely discussed in the document. However, in those few passages where it is discussed, a new kind of industry is envisioned - a high-end one.

In the one short section in the Report which is devoted to the call centre industry, call centres are envisioned as providing "higher end jobs" in "niche services" and located in smaller centres in the province. Further it is stated that their "high end" nature will need "substantial investment" in community colleges, universities and training centres (Self-sufficiency Task Force Report, 2007: 20). Call centres come up again, briefly, in another section of the Report, where possible options for solving the population/labour force shortage are explored. It is claimed that there are 70,000 underemployed workers in New Brunswick and that these workers would be suitable for the new high value call centre jobs:

This group of people could help government attract companies that require a skilled labour force in niche areas such as information technology or business services [these include call centres] that cannot be relocated offshore (Self-sufficiency Task Force Report, 2007: 7).

One final mention of the industry is made under the heading "Getting the Incentives Right". It is noted that New Brunswick is presently lagging behind Nova Scotia in "the attraction of high-end business service jobs" (Self-sufficiency Task Force Report, 2007: 5). In order for New Brunswick to compete, the Report recommends going back to the McKenna approach:

...reasonable and customized incentives will be required from time to time, whether in the form of tax breaks, cash incentives, loan guarantees or labour force training. 
This strategy should be flexible to allow for the negotiation of packages that are tailored on a case-by-case basis (Self-sufficiency Task Force Report, 2007: 6).

\section{A Prediction for the Demise of the Industry}

A recent Statistics Canada study has caused a flurry, at least in the media, about the future of the call centre industry in the province (Vincent and McKeown, 2008). The authors of the study suggest that, despite a $27.7 \%$ annual increase in revenue in the Canadian industry as a whole over the 1998-2006 period, it is time for the industry to enter a new phase of the industry cycle from low cost labour to a higher value one.

In the study, which used 2005 data, the authors found support for their hypothesis that, "telephone call centres are disproportionately found in certain provinces, located in smaller urban areas with higher unemployment and a relatively educated labour force" (Vincent and McKeown, 2008: 6). New Brunswick is a prime example of this pattern. For example, the authors found a density of call centres in New Brunswick of 13.1 per 10,000 business establishments compared to a national average of 6.8 per 10,000 (Vincent and McKeown, 2008: 5). However, despite the province's past success with the growth of the industry using this model, the authors suggest that such factors as the high value of the Canadian dollar and increased offshore competition from India, China and other emerging economies will mean that the industry should move from "the lowest cost labour phase of the industry cycle" to "a higher value one in terms of technical and linguistic skills and technology" and be located near "research clusters and agglomerated economies" (Vincent and McKeown, 2008: 7).

Commentators in the region have agreed with the conclusions of the Statistics Canada study. David Chaundy, an economist at APEC (Atlantic Provinces Economic Council), also has questions about the future of the industry, or even its current success, given what he sees as a "see-saw trend" in the Connect North America departure from, and Atelka entry into, the Fredericton market (Hudon, 2008: online). He also feels that the old model of banking on low costs will not work anymore and recommends a move to higher value centres such as business to business, health and financial services. David Campbell, a business commentator from Moncton, responded in a similar way to the study:

A \$10-an-hour job pays very little provincial income tax or HST. Those jobs filled a need but now that we have low unemployment, we need to look for jobs that will contribute taxes that will pay for government services. Essentially, we were attracting jobs that did not generate enough taxes to pay for the government services covering the worker (Morris, 2008: online).

The call for the creation of high value jobs by centres operating in niche markets was 


\section{Telling the Story of Globalization, Neoliberalism and the Call Centre Industry in New Brunswick}

made in the Graham government's self-sufficiency agenda. However, there are serious questions about whether such centres can be attracted to the province and, if they do come, whether they will stay. The call for high value jobs in the industry has been made since the McKenna years yet few centres which could provide such jobs have come to the province. Moreover, one of the few that did come was Salesbridge, the business to business seller into which the government put so much money. That initiative ended very badly. The fact is that it is the global corporations which set up the so-called high value call centres that are the most footloose of any in the industry since they are the ones that area dependent on contracts, or sometimes just a single contract, from other global corporations.

\section{Concluding Comments: Globalization, Neoliberalism and the Call Centre Industry in New Brunswick}

At the rhetorical level, globalization and neoliberalism are used in New Brunswick as ideological doctrines, delivered with bravado. In the image on the cover of the McKenna Toward Self-sufficiency document and the language of 'high tech' and 'information highway', globalization appears to make New Brunswick a world player. The term neoliberalism is never used. Rather, it is the business model which is extolled. New Brunswick is 'to be run like a business' and 'open for business'. However, behind the business model rhetoric is the market fundamentalist ideology of neoliberalism.

It is implied, at the rhetorical level, that both globalization and neoliberalism, in the form of the business model, will bring prosperity to the province. However, below the surface, there is an underlying desperation. The 'threat of foreign competition' is such that 'there is no alternative' to doing what corporations want- namely creating an investment climate in the province that is more attractive than that offered in any competing jurisdiction.

In practice, globalization in the New Brunswick case entails enticing foreign corporations to set up in the province while neoliberalism entails the adoption of policies that will get them here. The set of policies which have been adopted in New Brunswick involving incentives, tax cuts, cuts to the social safety net, deregulation and a lack of union support very much fit the definition of neoliberalism although such adoption takes place without either the use of the term or the articulation of the policies implemented under it as a package. Further, while neoliberalism may be 'declared dead' in other jurisdictions, in New Brunswick it is becoming stronger. The latest proposed changes in the tax regime, using the Irish model, attest to this.

Combining the terms and calling what is going on 'neoliberal globalization' in the sense of 'the globalization of neoliberalism' and the domination of global corporations or the new imperialism seems to fit the New Brunswick case very well. Radice's description (quoted earlier) of the elements of neoliberal globalization as including the ideology of international competition, the message to workers of having to be "low cost", the domestic 
politics of TINA ("there is no alternative"), the cutting of welfare, privatization, and deregulated labour markets in order "to manage labour on behalf of capital" could have been written for the New Brunswick case. Of course, in fact, it also describes a multitude of other cases in both the North and the South.

There is the question of the intentionality as opposed to the inevitability of globalization in terms of the role of the global corporations in New Brunswick. We read that politicians and their associates sit on boards of corporations where they learn what the latter want. We also read that the corporations 'play hard-to-get'. The jurisdiction has to offer more and more as one jurisdiction is played off against others. Yet the corporations have no loyalty. They leave when they want to and show little concern for the workers - or the province for that matter - when they do. All of this suggests that it is the corporations which are imposing the agenda or, to put it in another way, that in New Brunswick, at least, the interpretation of globalization as intentional is supported.

The question of the role of the state as victim or actor can also be addressed from the perspective of New Brunswick. As has been shown in this paper, it has been the state - the province of New Brunswick in this case - which has been a major actor in bringing 'globalization' to its jurisdiction. It has 'created', and is trying to expand, New Brunswick's call centre industry by using neoliberal policies to change the policy regime. In this, it has been supported by the federal state, through the latter's implementation of its own neoliberal policy regime. While the province portrays itself as a victim by suggesting that 'there is no alternative', it most certainly is an actor in its choice of strategy and policies since there are, clearly, alternatives it could have pursued. It is worth noting that the price that New Brunswickers have had to pay in terms of changes to the policy regime are, in some ways, higher than that which would have been required by the creation of a free trade zone, a common approach taken in the South. In New Brunswick, the changes made to the tax regime and regulations apply within the whole province not just to corporations operating within a free trade zone.

New Brunswick's recent neoliberal strategy has brought new contradictions: unprotected workers in a footloose industry rejecting unions; a call for further job creation in the call centre industry despite a labour shortage and the prediction of the demise of the industry; the government's enthusiastic support for the creation of low value rural call centres while declaring the need for high value ones; and, finally, the pursuit of 'self-sufficiency' by increasing the dependency on foreign capital of an industry that is already so vulnerable. None of these emerging contradictions bodes well for the future of the call centre industry in New Brunswick.

There remains the question of whether such globalization and neoliberal approaches using 
a call centre strategy are really anything new for New Brunswick. I have explored this theme in relation to the call centre strategy of the nineties in two previous papers. The question was asked in two somewhat different ways. In one it was whether the call centre strategy is "a new solution to an old problem"13 and in the other it was whether the strategy is "old wine in new bottles" (Buchanan and McFarland, 1997: 99). Considering not only the nineties but also the recent developments in the industry discussed above, the answer would still have to be that the problem may be old, as may be the 'globalization' approach of attracting investment to the province, but the industry is new, the type of jobs is new, the type of transnational corporations coming to the province is new and neoliberal policies are new.

In the earlier era, the drive was to attract investment to the resource industries of New Brunswick - particularly forestry and mining. The jobs in these industries were for males, high paying and unionized. The transnationals that are being attracted now are BPOs which are quite different from the resource companies that came earlier. The BPOs are footloose and the jobs they create are just the opposite of those before- predominantly female, low paying and non-unionized. The neoliberal policies of the McKenna and Graham eras can be contrasted to the earlier policy directions of Louis Robichaud in the late 1960's with his program of equal opportunity and perhaps to a lesser extent with those of Conservative Richard Hatfield in making New Brunswick Canada's first bilingual province. Hatfield did make an ill-fated entry into the business of using incentives to attract investment to the province in the production of the gull-winged Bricklin sports car in the mid-seventies (Fredericks, 1977). However the outcome of that debacle pales in comparison with that of recent neoliberal policies in terms of the harshness of their impact on workers and the people of New Brunswick. 


\section{REFERENCES}

Accenture Web Site. www.accenture.com

Atelka Web Site. www.atelka.com

Berry, Shawn. 2007. “32 Jobs Lost.” Daily Gleaner, Fredericton, 6 June. Online: http://www.fpinfomart.ca

Buchanan, Ruth and Joan McFarland. 1997. "The Political Economy of New Brunswick's Call Centre Industry: Old Wine in New Bottles?" Socialist Studies Bulletin, 50, October-December.

Buchanan, R. and S. Koch-Schulte. 2000. Gender on the Line: Technology, Restructuring and the Reorganization of Work in the Call Centre Industry. Ottawa: Status of Women Canada.

CBC. 2007. "Cut Corporate Taxes, NB government Advised.” 19 October. Online: http:www.cbc.ca/canada/new-brunswick/story/2007/10/19/cut-taxes.html. Retrieved 20/4/2008.

Centrebeam Web Site. www.centrebeam.com

Ceridian Canada. 2008. "New Brunswick Budget 2008-09 - Items Affecting Payroll." Online: http:www.ceridian.ca/en/resources/budget-nb.html. Retrieved 4/20/2008.

ClientLogic Web Site. www.localmoncton.com

Coburn, Elaine. 2003. "Interrogating Globalization: Emerging Contradictions and Conflicts.” In Global Shaping and its Alternatives. Yildiz Atasoy (ed.). Peterborough: Broadview Press, pp. 111-136.

CUPE. 2008. "Pig in a Poke: New Brunswick's Discussion Paper on Tax Reform." Submission to the New Brunswick Legislative Assembly, 9 July.

Daily Gleaner. 1995. "Premier Challenged on Job Creation.” Fredericton: 2 August

Daily Gleaner. 2004. "New Brunswick Laws Foiled in Call Centre Layoffs: Official." Fredericton: 31 July.

Daily Gleaner. 2007. “32 Jobs Lost.” Fredericton: 6 June. 
Duplain, Richard. 2005. “Job Boost of 300 for City.” Daily Gleaner. Fredericton: 20 July.

Ellwood, Wayne. 2006. The No-Nonsense Guide to Globalization, 2nd edition. Toronto: New Internationalist.

Erskine, Bruce. 2008. "Halifax Call-Centre to Lay Off 485.” Herald. Halifax: 26 Feb. Online: www.fpinfomart.ca

Fredericks, H.A. with A. Chambers. 1977. Bricklin. Saint John: Brunswick Press.

Good, Tom and Joan McFarland. 2004. "Technology, Gender and Regulation: Call Centres in New Brunswick." In Challenging the Market: The Struggle to Regulate Work and Income. Jim Stanford and Leah F. Vosko (eds.). Montreal \& Kingston: McGill-Queen's University Press, pp. 146-164.

Good, Tom and Joan McFarland. 2005. "Call Centres: A New Solution to an Old Problem?" In From the Net to the Net: Atlantic Canada and the Global Economy. James Sacouman and Henry Veltmeyer (eds.). Aurora, Ontario: Garamond, pp. 99-113.

Hrabluk, L. and M. Tutton. 1999. "Ten Years into the Call Centre Era, Critics are Questioning the Payback.” New Brunswick Telegraph Journal. Saint John: 20 March.

Hudon, Marc. 2008. "Call-Centre Industry Must Adapt - Economist.” Daily Gleaner. Fredericton: 29 February. Online: www.fpinfomart.ca

InPro Solutions. 2006. Business Process Outsourcing and Customer Contact Center Industry Profile, Greater Fredericton Region. Online: http://www.investfredericton.com. Retrieved 6/12/2007.

Jackson, A., and D. Robinson with B. Baldwin and C. Wiggins. 2000. Falling Behind: The State of Working in Canada, 2000. Ottawa: Canadian Centre for Policy Alternatives.

Lee, Philip. 2001. Frank: The Life and Politics of Frank McKenna. Fredericton: Goose Lane Editions.

Lepage, Gilles and Francis McGuire. 2007. "Province Must Fashion its own Set of Keys.” Times and Transcript. Moncton: 12 March. Online: www.fpinfomart.ca 
Lewis, Eric. 2008. "Fredericton Rates High Among Top Places to do Business in Atlantic Canada.” Daily Gleaner: Fredericton, 28 March. Online: www.fpinfomart.ca

Llewellyn, Stephen. 2007. "Call Centres Close Suddenly; Hundreds of Workers out of Work as Company Padlocks Fredericton, Bathurst Centres.” Times and Transcript. Moncton: 30 August.

Llewellyn, Stephen. 2007. "Tougher Labour Laws Needed in Wake of Call-Centre Closure, Says New Democrat; Interim NDP Leader says Employer Taking Advantage of Workers at Connect North America." Daily Gleaner. Fredericton: 1 Sept.

Little, B. 1998. "Why So Many Jobless Don’t Get UI.” Globe and Mail. Toronto: 26 October.

Malik, K. and M. Tutton. 1999. "Call Centre Closure Plans Anger Saint John Workers.” New Brunswick Telegraph. Saint John: 13 November.

Marketbridge Web Site. www.market-bridge.com

Maritime Provinces Higher Education Commission. 1998. Survey of 1996 University Graduates. Fredericton: Baseline Market Research.

McFarland, Joan. 1996. "Many Are Called, But What Are the Choices?" New Maritimes. July/August.

McFarland, Joan. 2007. "Vulnerable Jobs in the New Brunswick Call Centre Industry." Paper presented at New Brunswick and Atlantic Studies Research and Development Centre Conference. Town and Country: Exploring Urban and Rural Issues in New Brunswick. St. Thomas University, June 22-23.

McLaughlin, Heather. 2003. "Workers Still Fighting for EI.” Daily Gleaner. Fredericton: 12 July.

Meagher, David. 1996. “\$28 Million in Aid to Call Centres: N.B. Puts Money Where Mouth Is.” Daily Gleaner. Fredericton: 1 May.

Meagher, David. 1996. "N.B. Makes Pitch in Several Ways: Call Center Capital of North America." Daily Gleaner. Fredericton: 2 May. 
Morris, Chris. 2008. “NB Urged to Call Up Higher Paying Jobs.” Daily Gleaner. Fredericton, 3 March.

Naiman, Joanne. 2004. How Societies Work: Class, Power and Change in a Canadian Context. Toronto: Thomson/Nelson.

New Brunswick Workers' Compensation Board. 1992. 74th Annual Report. Fredericton.

New Brunswick Department of Economic Development and Tourism. 1993. Toward Self-sufficiency: Strategy for Economic Development. Fredericton: April.

New Brunswick Department of Finance. 2007. The New Brunswick Economy 2007. Fredericton: 13 March.

New Brunswick Department of Finance. 2002. The New Brunswick Economy 2002. Fredericton: March.

New Brunswick/NBTel. 1999. From Start to State of Art. Saint John: New Brunswick Call Centre Team.

New Brunswick. 2007. The Self-sufficiency Task Force Report, Parts 1, 2 \& 3. Fredericton, January-March.

New Brunswick Communications. 2008. "Virtual-Agent Services Enters its Third Phase of Growth.” News Release: 14 April. Online: www.gnb.ca.

New Brunswick Telegraph Journal. 2004. "Call Centre Closing its Doors: More than 600 People will be out of Work with the Closure of RMH Teleservices in Oromocto." Saint John: 30 July. Online: www.fpinfomart.ca.

New Brunswick Telegraph Journal. 2007. "Harnessing the Power of VoIP Communications: How One Company used Voice-Over-Internet Protocol to Fuel Growth.” Saint John: 8 October. Online: www.fpinfomart.ca

New Brunswick Website. 1996. www.cybersmith.newbrunswick.

Panitch, Leo. 2003. "Globalization Begins (and Ends) at Home: Bringing the State Back." In Global Turbulence: Social Activists' and State Responses to Globalization. Marjorie Griffin Cohen and Stephen McBride (eds.). Burlington VT: Ashgate, pp. 13-25. 
Petras, James and Henry Veltmeyer. 2001. Globalization Unmasked: Imperialism in the 21st Century. Halifax: Fernwood.

Radice, Hugo. 2005. "Neoliberal Globalization: Imperialism without Empires?” In Neoliberalism: A Critical Reader. Alfredo Saad-Filho and Deborah Johnston (eds.). London: Pluto Press.

Saad-Filho, Alfredo and Deborah Johnston. 2005. Neoliberalism: A Critical Reader. London: Pluto Press.

Shipley, David. 2007. "Ringing in Era of Stability: Province's Call Centre Industry Reaches State of High-Tech Maturity.” New Brunswick Telegraph Journal. Saint John, 4 June.

Sinclair, Scott and John Jacobs. 2007. Atlantica: Myth and Realities. Toronto: Canadian Centre for Policy Alternatives.

Statistics Canada. 1999. 71-001-XPB. Various issues. The Labour Force. Ottawa.

Statistics Canada. 2000. 71-201-XPB. Historical Labour Force Statistics. Ottawa.

Stiglitz, Joseph E. "The End of Neo-liberalism?” Project Syndicate. Online: www.project-syndicate.org. Retrieved 7/18/2008.

Times and Transcript. 2006. "Minacs Doesn't Plan to Transfer Jobs to China: CEO." 27 June.

Times and Transcript. 2007. "Laid-off N.B. Call Centre Workers get Last Paycheques: Former Employees of Connect North America Still Bitter over Sudden Closure of Centre.” Moncton: 8 September.

Vincent, Richard and Larry McKeown. 2008. Trends in the Telephone Call Centre Industry. Ottawa: Statistics Canada. February. 